\title{
Environmental and Socio-Legal Assessments of the Cultivation of Non-Consumed Asian Green Mussel (Perna Viridis) in the Coastal Areas of the Jakarta Bay
}

\author{
Untoro $^{1,2 *}$, Lazarus Tri Setyawanta ${ }^{1}$, Esmi Warassih Rahayu ${ }^{1}$, Raihan $^{2}$ \\ ${ }^{1}$ Universitas Diponegoro, Semarang, Indonesia \\ ${ }^{2}$ Universitas Islam Jakarta, Jakarta, Indonesia
}

Received: 06/06/2020

Accepted: 08/10/2020

Published: 20/12/2020

\begin{abstract}
Utilization of the waters of the northern coast of Jakarta which are contaminated with heavy metals as a conservation area through a non-consumed Asian green mussel (perna viridis) cultivation program as an aspired law. This research method is qualitative with socio-legal approach as a basis for the formation of non-consuming green seashell. The results showed that green mussels have the advantage of being a bio filter because they are able to filter water contaminated with heavy metals. Its ability shows that 1 kilogram of green mussels can filter water as much as 10 liters/hour. Testing results in the sea water in Kamal Muara and Cilincing in 2019 showed that the heavy metal content of lead $(\mathrm{Pb})$ and cadmium $(\mathrm{Cd})$ and mercury $(\mathrm{Hg})$ did not meet the standards of the Minister of Environment Decree Number 179 of 2004. The test results at the ordinate point of the sampling location Kamal Muara S6 ${ }^{0}$ ' $^{4} 1$, 16972"/E106 44'24,00684" (Station I) showed an increase in $\mathrm{Pb}$ of $0.052 \mathrm{mg} / \mathrm{l}$, making it very appropriate as the basis for nonconsumed green seashell cultivation area as this species was able to be an environmentally friendly bio filter.
\end{abstract}

Keywords: Environmental assessments, socio-legal perspectives, cultivation, non-consumed green mussel, coastal areas

\section{Introduction}

The north coast of Jakarta is located in the administrative city area of North Jakarta, with an area of $146.66 \mathrm{Km}^{2}$ plus the Thousand Islands with an area of $8.70 \mathrm{Km}^{2}$. The northern coastal area of Jakarta, including the waters of the Jakarta Bay coast, is a strategic area, but it is vulnerable to environmental damage caused by community activities. The 2019 data from the results of sea water testing in the waters of the Jakarta Bay, in Kamal Muara and Cilincing, show that the content of heavy metals leads $(\mathrm{Pb})$ and cadmium $(\mathrm{Cd})$ and mercury $(\mathrm{Hg})$ does not meet the standards of the Minister of Environment Decree Number 179 of 2004

Testing at the Ordinate Point of Sampling Location for Kamal Muara S604'41, 16972"/E106044'24,00684" (Station I), there was an increase in $\mathrm{Pb}$ of $0.052 \mathrm{mg} / \mathrm{l}$. Ordinate Point of Sampling Location S6 ${ }^{0} 428,23492$ "'E106044'28,7009" (Station II) there was an increase in $\mathrm{Pb}$ of $0.059 \mathrm{mg} / \mathrm{l}$; for cadmium (Cd) of $0.096 \mathrm{mg} / \mathrm{l}$. Ordinate Point Sampling Location S6 ${ }^{0}$ '41, 18,39028'/E106 44'21,37486" (Station III) there was an increase in $\mathrm{Pb}$ of $0.058 \mathrm{mg} / \mathrm{l}$. Ordinate Point Sampling Location S6 $6^{0}$ '58, 44563"/E106 44'12,08328" (Station IV) there was an increase in $\mathrm{Pb}$ of $0.057 \mathrm{mg} / \mathrm{l}$. Ordinate Point of Sampling Location S6 $6^{\circ} 38$,

Corresponding author: Untoro, (a) Universitas Diponegoro, Semarang, Indonesia and (b) Universitas Islam Jakarta, Jakarta, Indonesia
89596"/E106044'24,00684" (Station V) there was an increase in $\mathrm{Pb}$ of $0.076 \mathrm{mg} / \mathrm{l}$. The average increase of the five stations was $0.337 \mathrm{mg} / \mathrm{l}$. Testing at the Ordinate Point of Sampling Location Cilincing S604'55, 86456"'E106 $056^{\prime} 29,10732$ "' (Station I) there was an increase in $\mathrm{Pb}$ of $0.043 \mathrm{mg} / \mathrm{l}$. Measurements at the Ordinate Points of Collection S6 ${ }^{0} 4^{\prime} 54$, 156 "/E 106 55'57,5166" (Station II) there was an increase in $\mathrm{Pb}$ of $0.033 \mathrm{mg} / \mathrm{l}$. Tests at the Ordinate Point of Collection Location S6 $6^{0}$ '18, 2445"/E106 55'51,56256" (Station III) there was an increase in $\mathrm{Pb}$ of $0.068 \mathrm{mg} / \mathrm{l}$. Tests at the Ordinate Point of Collection Location S6 $3^{\prime}$ '46, 05172"/E106 $55^{\circ} 42,532$ " (Station IV) there was an increase in $\mathrm{Pb}$ of $0.049 \mathrm{mg} / \mathrm{l}$. The increase in mercury $(\mathrm{Hg})$ is $0.003 \mathrm{mg} / \mathrm{l}$. Measurements at the Ordinate Point of Collection Location $\mathrm{S}^{0} 3^{\prime} 50,6443$ "/E106 $55^{\prime} 39,6130^{\prime \prime}$ (Station V) there was an increase in $\mathrm{Pb}$ of $0.049 \mathrm{mg} / \mathrm{l}$. The average increase of the five stations is $0.2058 \mathrm{mg} / \mathrm{l}$ rounded off to $0.206 \mathrm{mg} / \mathrm{l}$.

This condition is due to the 13 rivers that flow and empties into Jakarta Bay from west to east, based on the 2018 records from the Indonesian Institute of Sciences that 21 tons of garbage every day enters Jakarta Bay, that are Kamal River, Angke River, Mookevaart River, Grogol River, Ciliwung River, Ancol River, Cakung River, Blencong River, Sunter River, Kali Baru River, Bekasi River, Krama River, Citarum River or Muara Gembong. This has led to the idea that it is necessary to cultivate non-consuming green seashell fish as a bio filter in the waters of Jakarta Bay. Green mussels (perna viridis) also known as green mussels have a high economic 
value. The physical characteristics of green seashell have a pair of shells that are slightly bluish green. Having multiple layers of gills, waters with a depth of $1 \mathrm{~m}$ to $7 \mathrm{~m}$ are a suitable place for green seashell to live. There are coastal waters, mangrove areas and river estuaries [1]. Green mussels have the ability to survive and reproduce under high ecological pressure without experiencing significant disturbance. In addition, green clams have a high protein content (4.7) compared to other animal proteins such as beef (18.8), lamb (17.1), and chicken (18.2). However, the results of the study indicate that green clams taken from the north coast of Jakarta are not suitable for consumption because they contain lead levels that have exceeded the $0.01-1.00 \mathrm{ppm}$ threshold set by the authorized institution from Indonesian Food and Drug Supervisory Agency. Therefore, juridical, steps are needed that are in line with the concept of cultivating non-consuming green seashell in coastal waters contaminated with heavy metals on the north coast of Jakarta.

The aims of this study are to assess the cultivation of nonconsuming green mussels in coastal waters contaminated with heavy metals and the implication of the concept of cultivating non-consuming green seashell in coastal waters on the north coast of Jakarta.

\section{Research Methods}

This research is a qualitative research which is a multiple method in focus, involving an interpretive and reasonable approach to each problem being studied. In other words, qualitative research works in a natural setting that seeks to provide and understand interpretations of phenomena as seen from the meaning people give to these phenomena. Qualitative research emerged as a result of a reaction to the positivism and post-positivism traditions which attempted to conduct cultural studies with an interpretive character [2]. Qualitative research involves the use and collection of various empirical materials, namely case studies, observations, interviews. Meanwhile, data validation was carried out using triangulation techniques. This research approach is socio-legal research with a participatory paradigm which has consequences for research methodology, ontology and epistemology, as well as axiology that is different from other paradigms. The character of the socio-legal research method can be identified through two things: first, socio-legal studies do textual studies, articles in laws and regulations and policies are analyzed critically, their meaning is explained. So that the socio-legal study also discusses the constitution to the lowest statutory regulations, as well as judges' decisions. Second, socio-legal studies develop various new methods resulting from the marriage between legal methods and social science, such as socio-legal qualitative research [3]. The data used are primary data, secondary data consisting of primary legal materials and secondary legal materials by using the advocacy in "A" model (Figure 1).

\section{Results and Discussion}

\subsection{Cultivation of Non-Consumed Green Seashell Contaminated with Heavy Metals on the Coastal Waters of Jakarta}

The concept of non-consuming green seashell fish cultivation in coastal waters contaminated with heavy metals is related to the utilization of the spatial pattern of the northern coast of Jakarta. Article 1 point 4 of Law No. 26 of 2007 concerning Spatial Planning states "spatial pattern is the distribution of spatial use in an area which includes space allocation for protection functions and spatial designation for cultivation functions. The meaning of spatial patterns is the division and distribution of space designation, so that the designation of coastal waters which have been contaminated with heavy metals is directed towards the concept of forming a non-consumed green seashell cultivation area. Henceforth, if the waters of Jakarta Bay return to normal, it can be directed as a fishing ground. As explained in the previous paragraph, the existing conditions in the northern coast of Jakarta have exceeded the quality standard, along with the 2010 data from measurements carried out in the framework of the EIA study on residential development and integrated Green Bay businesses, showing that the quality of sea water has exceeded the quality standard according to the Decree of the Minister of Environment Number: Kep-51/MENLH/2004 concerning Sea Water Quality Standards. The following table shows the quality of seawater in Pluit Utara in 2010 based on an EIA study on the integrated residential and business development of Green Bay.

The measurement results above show that the coastal waters in North Pluit are relatively cloudy, this is due to the very significant influence of land activities. Several parameters indicated that it did not meet the quality standard, such as DO, total ammonia, phosphate, nitrate and biological parameters. The occurrence of turbidity in water bodies will disrupt marine cultivation businesses such as floating net cages and marine ecosystems. In February 2013, measurements of sea water quality were also carried out, which showed the same indication, namely the condition of sea water quality that exceeded the quality standard by several physical and chemical parameters. Several parameters of sea water quality around Island $\mathrm{G}$ for several parameters have exceeded the seawater quality standard for marine biota. It is estimated that pollutants come from domestic waste discharged into water bodies, this is indicated by the high concentration of ammonia, oil and fat, fecal coliform, waste and metal waste, namely copper $(\mathrm{Cu})$, cadmium $(\mathrm{Cd})$, zinc $(\mathrm{Zn})$, lead $(\mathrm{Pb})$.

The heavy metal lead $(\mathrm{Pb})$ is toxic to humans and can cause acute and chronic poisoning. Acute poisoning includes a burning sensation in the mouth. Chronic symptoms are generally characterized by nausea, anemia, pain around the mouth, and can cause paralysis. Cadmium (Cd) is not needed by the human body for human function and growth because it is very toxic to humans. Acute poisoning will cause terointestinal gas and kidney disease. Mercury or Mercury $(\mathrm{Hg})$ is dangerous because it is bio magnification so that it can accumulate in the tissues of organisms through the food chain [4]. The concept of non-consumed green seashell fish cultivation needs to be done because the green clams have the ability to absorb polluted water so that the waters of Jakarta Bay become clean water according to standards. The ability of green clams as a bio filter has been proven by the Ancol conservation team in their research which shows that 1 kilogram of green clams can filter 10 liters of water per hour [5]. In an interview, Ir. Sartono, Head of the DKI Jakarta Province Fishery Products Inspection and Certification Production Center on March 18, 2019 stated that after the waters of Jakarta Bay are clean according to standards it can be formed as a fishing ground. For this, it can be done by drowning the fish house (FAD) to gather the fish as a shelter. This is a way to empower fishermen in managing artificial fishing ground for fishermen's welfare. Fishermen are given the opportunity to participate in managing an artificial fishing ground. Like how to catch fish whether it will be done with a net or fishing. This management can be handed over on the basis of deliberation and consensus between fishermen. 
Table 1: Seawater Quality Measurement Results in North Pluit

\begin{tabular}{|c|c|c|c|c|c|}
\hline No & Parameter & Unit & Quality Standards ${ }^{1}$ & $\mathrm{AL}-1^{2}$ & $\mathrm{AL}-2^{2}$ \\
\hline & Physical assesment & & & & \\
\hline 1 & Brightness & Meter & $\begin{array}{l}\text { Coral >5 } \\
\text { Mangrove/ } \\
\text { seagrass >3 }\end{array}$ & 0.5 & 0.5 \\
\hline 2 & Turbidity & NTU & $<5$ & 9 & 26 \\
\hline 3 & TSS & $\mathrm{mg} / \mathrm{l}$ & $\begin{array}{l}\text { Coral } 20 \\
\text { Mangrove } 80 \\
\text { seagrass } 20\end{array}$ & 15 & 29 \\
\hline \multirow[t]{2}{*}{4} & Temperature & ${ }^{0} \mathrm{C}$ & $\begin{array}{l}\text { Coral 28-30 } \\
\text { Mangrove 28-32 } \\
\text { seagrass 28-32 }\end{array}$ & 27.0 & 27.0 \\
\hline & Chemical assesment & & & & \\
\hline 1 & $\mathrm{pH}$ & - & $7-8.5$ & 7.8 & 7.9 \\
\hline 2 & Salinity & $0_{00}$ & Natural & 19.4 & 21.4 \\
\hline 3 & Dissolved Oxygen (DO) & $\mathrm{mg} / \mathrm{l}$ & $>5$ & 2.4 & 2.0 \\
\hline 4 & BOD & $\mathrm{mg} / \mathrm{l}$ & 20 & 28 & 25 \\
\hline 5 & Total Ammonia $\left(\mathrm{NH}_{3}-\mathrm{N}\right)$ & $\mathrm{mg} / \mathrm{l}$ & 0.3 & 5.44 & 5.18 \\
\hline 6 & Phosphate $\left(\mathrm{PO}_{4}-\mathrm{P}\right)$ & $\mathrm{mg} / \mathrm{l}$ & 0.015 & 0.73 & 0.51 \\
\hline 7 & Nitrate $\left(\mathrm{NO}_{2}-\mathrm{N}\right)$ & $\mathrm{mg} / \mathrm{l}$ & 0.008 & 1.2 & 1.2 \\
\hline 8 & Cyanide $(\mathrm{CN})$ & $\mathrm{mg} / \mathrm{l}$ & 0.5 & $<0.005$ & $<0.005$ \\
\hline 9 & Sulfide $\left(\mathrm{H}_{2} \mathrm{~S}\right)$ & $\mathrm{mg} / \mathrm{l}$ & 0.01 & $<0.002$ & $<0.002$ \\
\hline 10 & Phenol & $\mathrm{mg} / \mathrm{l}$ & 0.002 & $<0.001$ & $<0.001$ \\
\hline 11 & Anionic Surfactants (MBAS) & $\mathrm{mg} / \mathrm{l}$ & 1.0 & 0.11 & 0.16 \\
\hline 12 & Oil and fat & $\mathrm{mg} / \mathrm{l}$ & 1.0 & 0.2 & 0.2 \\
\hline 13 & Mercury (Hg) & $\mathrm{mg} / \mathrm{l}$ & 0.001 & $<0.0005$ & $<0.0005$ \\
\hline 14 & Chromium $\left(\mathrm{Cr}^{6+}\right)$ & $\mathrm{mg} / \mathrm{l}$ & 0.005 & $<0.005$ & $<0.005$ \\
\hline 15 & Arsenic (As) & $\mathrm{mg} / \mathrm{l}$ & 0.012 & $<0.002$ & $<0.002$ \\
\hline 16 & Cadmium $(\mathrm{Cd})$ & $\mathrm{mg} / \mathrm{l}$ & 0.001 & $<0.0005$ & $<0.0005$ \\
\hline 17 & Copper $(\mathrm{Cu})$ & $\mathrm{mg} / \mathrm{l}$ & 0.008 & $<0.0005$ & $<0.0005$ \\
\hline 18 & Lead $(\mathrm{Pb})$ & $\mathrm{mg} / \mathrm{l}$ & 0.008 & $<0.005$ & $<0.005$ \\
\hline 19 & Zinc $(\mathrm{Zn})$ & $\mathrm{mg} / \mathrm{l}$ & 0.05 & 0.0182 & 0.0266 \\
\hline \multirow[t]{2}{*}{20} & Nickel (N) & $\mathrm{mg} / \mathrm{l}$ & 0.05 & $<0.002$ & $<0.002$ \\
\hline & Microbiology & & & & \\
\hline 1 & Coliform & MPN/100 ml & Nil & 460 & 210 \\
\hline 2 & Pathogenic Bacteria & $\mathrm{Sel} / 100 \mathrm{ml}$ & Nil & Positive & Positive \\
\hline
\end{tabular}

Source: Environmental Impact Analysis of the G Island Reclamation Plan of the Reclamation Area of Jakarta

3.2 Implications of the Non-consumed Green Seashell Cultivation in Contaminated Waters on the Jakarta Bay

There are two implications for this concept as revealed from the interview with the stakeholder. First, it has juridical implications, namely the aspect of policies related to waste disposal into rivers, licensing for non-consumed green mussels, RZWP3K which accommodates the establishment of an area for non-consumed green seashell fish cultivation. The second is the sociological implications of cooperation between DKI Jakarta Province, West Java Province and Banten Province.

The policy aspect regarding the discharge of waste into river flow is carried out by tightening the discharge of heavy metal by making policies related to the discharge of waste into the waters of 13 rivers that empties into Jakarta Bay. For example, waste disposal from households, industrial waste, and agricultural waste. It is necessary to make strict regulations into the wastewater treatment plant (IPAL) regulations. Two things are needed for this, first vertical coordination to reach an understanding between the Governor of Banten, the Governor of West Java and the Governor of DKI Jakarta. Because the north coast of Jakarta is not only the Provincial Government of DKI Jakarta that has an interest but also the Provincial Government of Banten and the Provincial Government of West Java. The length of the coastline which becomes the authority of the DKI Jakarta Provincial Government is approximately $32 \mathrm{~km}$ from the entire length of the north coast of Jakarta. The second is the horizontal coordination, namely the harmonization of local regulations from the three provinces that regulate water discharge from upstream to downstream. The regional regulations produced as a result of the coordination of the three provinces are intended to integrate various sectorial plans, overcome management overlaps and resolve conflicts of use and authority, and provide legal certainty, which is in accordance with the development of values and needs of the changing community through development efforts [6]. This is to avoid discharges of waste water or water that has been contaminated with heavy metals directly to Jakarta Bay.

It is also need a cooperation aspect between DKI Jakarta Province and West Java Province and Banten Province. The three provinces must make a mutual agreement in order to preserve the environment of Jakarta Bay. In other words, cooperation is needed in river management from upstream (West Java and Banten) to downstream (Jakarta Bay). In this context, the concept of cultivating non-consumable green 
mussels in coastal waters contaminated with heavy metals on the north coast of Jakarta is a concept going the right way. There will be coastal waters that meet quality standards, which can then be used as artificial fishing ground which is expected that justice and welfare can be realized.

The concept of cultivating non-consumable green mussels can be based on the theory of Chart "A" for advocacy [7]. Advocacy is an effort to influence public policy through various forms of communication. Narrowly defined as the establishment of a movement determined by the authorities to guide or control the behavior of institutions, communities, individuals. This model is known as the "A" model because it stands for advocacy. Advocacy according to this concept has 6 steps, namely analysis; strategy; mobilization; action; evaluation; continuity. Another definition states that advocacy is an action used to change policies, positions or programs of various institutions or institutions (advocacy is an action directed at changing the changing the policies, positions or programs of any type of institution). The Center for Development and Population Activities (CEDPA) organization provides a definition of advocacy, which is working with others to make change or difference [7] (Figure 1).

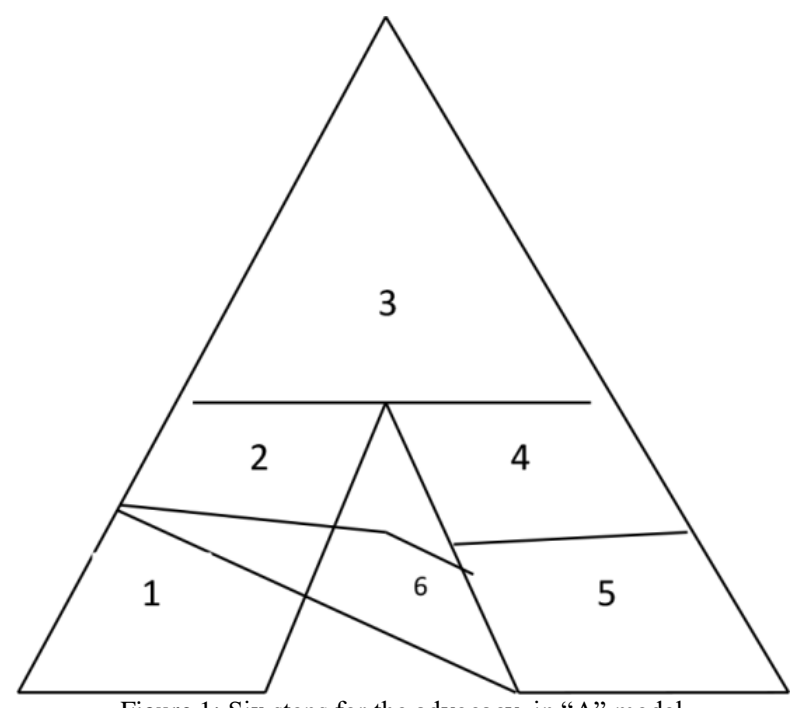

Figure 1: Six steps for the advocacy in "A" model

The six advocacy steps for the " $\mathrm{A}$ " model in the context of cultivating non-consumed green mussels in the coastal waters of the north coast of Jakarta can be explained as follows:

1.Analysis: the analysis was carried out on the concept of non-consumed green mussels.

2. Strategy: It was built on the basis of analysis stages that direct, plan and focus efforts on the specific objectives of the concept of non-consumed green seashell fish cultivation.

3. Mobilization: It is necessary to strengthen advocacy that can be carried out through outreach to the village level.

4. Advocacy: Advocacy action can be carried out by proposing the initiation of the formation of a regional regulation on zoning for DKI Jakarta, which in one of its provisions regulates the mandatory rehabilitation of the quality of the waters of the Jakarta Bay through the application of the concept of non-consumed green seashell fish cultivation.

5. Evaluation: Conducted on the strategy and implementation of non-consumed green seashell fish cultivation in the north coast of Jakarta.
6. Sustainability: Advocacy is an ongoing process. Sustainability clarifies the long-term goal of cultivating nonconsuming green mussels in the coastal waters of the north coast of Jakarta.

For more detail about strategy, it includes some strategies institutionally, legally and culturally. Institutionally, the DKI Jakarta Regional Government can collaborate to preserve the environment of Jakarta Bay with West Java and Banten Provinces so as to create strong coordination between DKI Jakarta Provincial Government with West Java and Banten Province to jointly preserve the Jakarta Bay. By law, the Governor of DKI Jakarta can stipulate by a Governor Regulation that polluted waters are used as places for cultivating non-consuming green seashell fish. Governor Regulation which regulates the disposal of waste containing heavy metals by establishing an integrated wastewater treatment plant (IPAL); revocation of licenses for industries that dispose of waste and cause pollution; the policy of the DKI Jakarta Regional Government which regulates the prohibition of rivers as backyards. In this connection the policies made must be effective, for this we need the best way to realize effective policies, namely through fostering partnerships between the private sector and the public at the local, national and international levels [8].

Legal culture preserves resources in coastal areas and small islands, not exploitation activities. This is in line with environmental ethics which is a collection of various principles of environmental morality that compile human morals with natural morals [9]. In the development of environmental ethics, there are several theories of environmental ethics, namely shallow environmental ethics, intermediate environmental ethics, deep environmental ethics, these three theories are known as anthropocentrism, biocentrism, and eco-centrism [9]. Legal culture respects customary/local communities. So that a substantial space for community participation is built to create synergy in the management of resources in coastal areas and small islands with development activities carried out by the DKI Jakarta Regional Government. Furthermore, legal culture manages the resources of coastal areas and small islands in a sustainable and integrated manner. The legal system emphasizes procedures but does not explain how people actually solve their problems in everyday life. The legal culture explains in detail the procedural legal values and substantive legal values [10]. Procedural legal values question the ways of organizing society and conflict management. The components of the substantive legal values of the legal culture consist of fundamental assumptions regarding the distribution and use of resources in society, especially regarding what is fair and unfair according to society. Thus, it can be said that the important element needed to be able to understand the differences between one legal system and another is legal culture.

The cultivation of non-consuming green mussels in the coastal waters of the north coast of Jakarta has a positive impact on traditional fishermen, which means that it provides legal protection for traditional fishermen. It can be used as a fishing ground. The establishment of a fish catchment area will one day show that the northern coast of Jakarta is not polluted or contains heavy metal lead $(\mathrm{Pb})$; Cadmium $(\mathrm{Cd})$; Mercury or Mercury $(\mathrm{Hg})$. In other words, it can be stated that waters that comply with standards are a right for traditional fishermen. There are two reasons for realizing the cultivation of non-consumed green mussels which will be followed by the formation of fish catchment areas. First, the juridical reason is 
that the existence of fishermen is protected by Law Number 7 of 2016 concerning the Protection and Empowerment of Fishermen, Fish Farmers and Salt Farmers. This Law stipulates the principle of fisherman sovereignty. Second, in terms of social and economic reasons, the contamination of Jakarta Bay waters, both from household waste and industrial waste, is the result of activities on land. In fact, fishermen, fish breeders, salt farmers depend on fish resources, healthy environmental conditions, and business certainty in fishing.

The establishment of an artificial fishing ground is capable of realizing just law because law and justice cannot be separated, when discussing legal issues it will come to justice. This means that law is not sufficiently discussed in its context as merely a formal structure $[11,12]$. Justice is the spirit for written legal norms because justice is able to direct and give life to written legal norms. Written law is likened to a human body that needs a spirit so that the human body can live. On the other hand, a spirit without a human body will result in not being alienated in life. A harmonious relationship between the spirit and the human body is indicated by the health of the human body, so when the human body is sick, surgery must be performed to maintain the continuity of the spirit in the human body. The sickness of the human body indicates a conflict of interest in the human body. This shows that if there is a conflict of interest between written law and justice, what can be done is to maintain justice because justice is the spirit of written law. Written legal norms are only a means of realizing justice so that it can be replaced or abandoned [1214]. So it takes a complete understanding of the law, not only understanding the law as the state law means. For this reason, legal empowerment is needed which is an effort to make the law empowered in realizing its legal goals or ideals, namely justice and prosperity for mankind itself so that the lower layers of society do not become weaker, poorer and helpless $[10,15,16]$

Legal empowerment in the context of non-consumed green seashell fish cultivation in the coastal waters of the north coast of Jakarta is carried out by involving traditional fishermen, starting from the planning stage. Thus it can be said that the legal empowerment of the use of coastal areas is carried out through the process of traditional fisherman participation. The meaning of traditional fishermen's participation is to make traditional fishermen have a role in the process of utilizing the north coast of Jakarta through nonconsumed green seashell fish cultivation. The strict and rigid application of the concept of utilizing the North coast of Jakarta (Mechanistic Action) will result in conflict. The example of a lawsuit against the reclamation permit for Island $\mathrm{G}$, Island $\mathrm{K}$, Island $\mathrm{I}$, Island $\mathrm{F}$ is evidence that strict and rigid application is not the optimal way to utilize the north coast of Jakarta. So that in applying the law it is necessary to do the Human Action Model. This model sees traditional fishermen as full of socio-cultural and dynamic values. In other words, the human action model provides a place for traditional fishermen to negotiate with power holders and the idea of traditional fishermen is an ingredient in the utilization of coastal areas.

The use of waters in coastal areas contaminated with heavy metals to serve as non-consumed green seashell is in accordance with the spirit of Pancasila, in accordance with the ideals of National Law Science or Pancasila. Law is oriented towards three pillars which are the balance value of Pancasila. First, oriented to the divine value that coastal areas and small islands are natural resources which are a gift from God Almighty, for that it is necessary to make conservation efforts.
Second, the human value that non-consumed green mussels cultivation on the one hand can empower fishermen, especially traditional fishermen, to be able to preserve coastal waters so that it can be enjoyed by both current and future generations. This is also in line with Indonesia as a welfare state. Third, the social value that coastal areas and small islands which have a high diversity of natural resource potentials are very important for social, economic, cultural, environmental development, and support the nation's sovereignty, therefore it needs to be managed in a sustainable and global perspective with pay attention to aspirations and participation, especially traditional fishermen, and national values based on national legal norms [17]. Ideals of law can be understood as a thought construction which is an imperative to direct the law to the ideals desired by society. Without legal ideals, the resulting legal product will lose its meaning [18]. The first precepts of the Supreme Lordship include and animate the next four principles: just and civilized humanity, Indonesian unity, democracy led by wisdom in deliberation/representation, social justice for all Indonesian people.[19] This is to resolve the heavy contaminated of Jakarta Bay and to make sustainable development for people based on national values.[20-24]

\section{Conclusion}

The concept of cultivating non-consuming green mussels in contaminated coastal waters with heavy metals on the north coast of Jakarta is an ius constituendum. It is need a cooperation aspect between DKI Jakarta Province and West Java Province and Banten Province. The three provinces must make a mutual agreement in order to preserve the environment of Jakarta Bay. In other words, cooperation is needed in river management from upstream (West Java and Banten) to downstream (Jakarta Bay). Because until now there has been no policy from the cooperation of three local governments (DKI Jakarta, Banten, West Java) to apply the concept of cultivating green seashell fish for non-consumed or not for consumption. The reason for the importance of this concept is because green seashell has the ability to absorb polluted water so that the waters of Jakarta Bay become clean water according to standards. After the waters of Jakarta Bay are clean according to standards, it can be formed as a fishing ground. The ability of green mussels as a bio filter shows that $1 \mathrm{~kg}$ of green mussels can filter polluted water as much as 10 liters/hour.

There are two implications of the concept of cultivating non-consuming green mussels in coastal waters contaminated with heavy metals on the north coast of Jakarta as an ius constituendum. There are two aspects of policy related to the discharge of waste into river flows. The second is the cooperation between DKI Jakarta Province and West Java Province and Banten Province. The policy aspect related to the discharge of waste into river streams is carried out by tightening the discharge of heavy metals by making policies related to the discharge of waste into the waters of 13 rivers that empties into Jakarta Bay. For example, waste disposal from households, industrial waste, and agricultural waste. It is necessary to make strict regulations into the wastewater treatment plant (IPAL) regulations. Two things are needed for this, first vertical coordination to reach an understanding between the Governor of Banten, the Governor of West Java and the Governor of DKI Jakarta. Because the north coast of Jakarta is not only the Provincial Government of DKI Jakarta that has an interest but also the Provincial Government of Banten and the Provincial Government of West Java. The 
length of the coastline which becomes the authority of the DKI Jakarta Provincial Government is approximately $32 \mathrm{~km}$ from the entire length of the north coast of Jakarta. The second is the horizontal coordination, namely the harmonization of local regulations from the three provinces that regulate water discharge from upstream to downstream. This is to avoid discharges of waste water or water that has been contaminated with heavy metals directly to Jakarta Bay. Here, it is also need a Cooperation aspect between DKI Jakarta Province and West Java Province and Banten Province. The three provinces must make a mutual agreement in order to preserve the environment of Jakarta Bay. In other words, cooperation is needed in river management from upstream (West Java and Banten) to downstream (Jakarta Bay).

\section{Ethical issue}

Authors are aware of, and comply with, best practice in publication ethics specifically with regard to authorship (avoidance of guest authorship), dual submission, manipulation of figures, competing interests and compliance with policies on research ethics. Authors adhere to publication requirements that submitted work is original and has not been published elsewhere in any language.

\section{Competing interests}

The authors declare that there is no conflict of interest that would prejudice the impartiality of this scientific work.

\section{Authors' contribution}

All authors of this study have a complete contribution for data collection, data analyses and manuscript writing.

\section{References}

1. Cappenberg HA. Some aspects of the Biology of the Green Mussel (Perna viridis, Linnaeus 1758).

2. Salim A. Social Research Theory and Paradigm: Second edition of the Resource Book for Qualitative Research. Yogyakarta: Tiara Wacana. 2006.

3. Irianto S. Introducing the Socio-Legal Study and Its Methodological Implications, in Adriaan W. Bedner, et al (Ed.). Socio-Legal Studies. Denpasar: Pustaka Larasan. 2012.

4. Said NI. Methods of removing heavy metals (As, Cd, Cr, Ag, Cu, $\mathrm{Pb}, \mathrm{Ni}$ and $\mathrm{Zn}$ ) in industrial wastewater. Journal of Air Indonesia, 2010;6(2)

5. Kompas.com. (2019). 3 Tons of Green Shells Spread in Ancol to Clear Jakarta Bay. Kompas.com, Oct 6, 2019. Retrieved from https://megapolitan.kompas.com/read/2019/10/06/10245541/3-tonkulit-kerang-hijau-ditebar-di-ancol-untuk-jernihkan -Jakarta Bay 6. Setyawanta LT. Coastal Zone Management Regulatory Reform in Indonesia and Challenges in Its Implementation in Regions. Inauguration Speech at the Admission Ceremony for Professor of Law at the Faculty of Law, Diponegoro University, Semarang. Semarang: Diponegoro University. 2009.

7. Pratomo H. Advokasi Konsep, Teknik dan Aplikasi di Bidang Kesehatan Indonesia. Jakarta: Litbang Kemkes. 2019.

8. Samekto FA. Capitalism, modernization \& environmental degradation. Pustaka Pelajar. 2005.

9. Raihan. Environment and Environmental Law. Jakarta: Jakarta Islamic University. 2013.

10. Warassih E, Medan KK, Mahmutarom. Legal Institutions: A Sociological Study. Suryandaru Utama. 2005.

11. Rahardjo S. Legal studies. Bandung: Alumni. 1986.

12. Mahmutarom HR. Reconstruction of the concept of justice: the study of the protection of victims of crime against life in positive law, Islamic law, construction of society and international instruments. Diponegoro University Press. 2009.
13. Saraswati R, Ristyawati A, Basworo RS. Recent developments and changes in the governance of regional legal products in Indonesia: Supervision, evaluation and clarification mechanisms. International Journal of Innovation, Creativity and Change. 2020;12(7):1-9

14. Tienh AL, Ristyawati A, Soemarmi A, Saraswati R. The national defense strategy under the regime of the 7th President of Indonesia to protect the exclusive economic zone of the Natuna Sea overlapping with China's nine-dash line. Aquaculture, Aquarium, Conservation \& Legislation. 2020 Aug 1;13(4):1993-2001.

15. Azhar M, Solechan S, Saraswati R, Suharso P, Suhartoyo S, Ispriyarso B. The New Renewable Energy Consumption Policy of Rare Earth Metals to Build Indonesia's National Energy Security. InE3S Web of Conferences 2018 (Vol. 68, p. 03008). EDP Sciences. 16.

17. Arief BN. Development of the National Legal System (Indonesia). Public Lecture at the Master of Law Science Program, UBH Postgraduate Program, Padang. 2012.

18. Lumbanraja AD, Musyafah AA, Saraswati R, Indreswari TL. The effect of gpa igr-4 on indonesian government policy on marine litter. AACL Bioflux. 2020;13(3):1758-1763

19. Savitri N, Gunarsa A. HAM perempuan: Kritik teori hukum feminis terhadap KUHP. Refika Aditama. 2008.

20. Latif Y. Negara Paripurna; Historisitas, Rasionalitas, dan Aktualisasi. Gramedia Pustaka Utama. 2012.

21. Hosono T, Su CC, Delinom R, Umezawa Y, Toyota T, Kaneko S, Taniguchi $M$. Decline in heavy metal contamination in marine sediments in Jakarta Bay, Indonesia due to increasing environmental regulations. Estuarine, Coastal and Shelf Science. 2011;92(2):297306.

22. Rees JG, Setiapermana D, Sharp VA, Weeks JM, Williams TM. Evaluation of the impacts of land-based contaminants on the benthic faunas of Jakarta Bay, Indonesia. Oceanologica Acta. 1999;22(6):627640 .

23. Takarina ND, Adiwibowo A. Impact of heavy metals contamination on the biodiversity of marine benthic organisms in Jakarta Bay. Journal of Coastal Development. 2011;14(2):168-171. 24. Siregar TH, Priyanto N, Putri AK, Rachmawati N, Triwibowo R, Dsikowitzky L, Schwarzbauer J. Spatial distribution and seasonal variation of the trace hazardous element contamination in Jakarta Bay, Indonesia. Marine Pollution Bulletin. 2016;110(2), 634-646.

25. Riani E, Cordova MR, Arifin Z. Heavy metal pollution and its relation to the malformation of green mussels cultured in Muara Kamal waters, Jakarta Bay, Indonesia. Marine pollution bulletin. 2018;133:664-670. 